\title{
Transfer efficiency of melamine from feed to milk in lactating dairy cows fed with different doses of melamine
}

\author{
J. S. Shen, ${ }^{*}$ J. Q. Wang, ${ }^{* 1}$ H. Y. Wei, † D. P. Bu, ${ }^{*}$ P. Sun, $†$ and L. Y. Zhou* \\ *State Key Laboratory of Animal Nutrition, Institute of Animal Science, Chinese Academy of Agricultural Sciences, Beijing, 100193, P. R. China \\ †Ministry of Agricultural Milk and Dairy Inspection and Supervision Center (Beijing), Beijing, 100193, P. R. China
}

\section{ABSTRACT}

This study was conducted to investigate the transfer efficiency of melamine (1,3,5-triazine-2,4,6-triamine) from feed to milk of lactating cows fed with different doses of melamine. Twenty-four China Holstein dairy cows were divided into 2 blocks according to milk yield (block 1 and block 2 for low- and high-producing cows). Cows of block 1 or block 2 each were randomly assigned to 1 of 4 treatments in a randomized complete block design and each treatment had 6 cows. The cows of treatments 1 to 4 were dosed with melamine at 0 (control), 90 (treatment 1), 270 (treatment 2), and 450 (treatment 3) mg/d per cow, respectively. The trial lasted $19 \mathrm{~d}$. During the first $13 \mathrm{~d}$, cows were fed melamine at the respective treatment levels, and the last $6 \mathrm{~d}$ was the clearance period after melamine was withdrawn. The results indicated that the levels of melamine used did not affect milk yield or composition. The mean milk melamine concentration increased during the initial $3 \mathrm{~d}$ after melamine feeding in all the melaminesupplemented groups, and then fluctuated slightly over the remaining $10 \mathrm{~d}$ of melamine feeding. No melamine was detected in the milk of any groups on d 4 of the clearance period. Milk melamine concentration measured between 3 to $13 \mathrm{~d}$ was significantly affected by melamine feeding doses, but was not influenced by milk yield. The transfer efficiency of melamine from feed to milk was not affected by melamine doses $(0.95,0.70$, and $0.66 \%$ for treatments 1,2 , and 3 , respectively), but was linearly related with milk yield $(0.56 \%$ for block 1 and $0.95 \%$ for block $\left.2, \mathrm{R}^{2}=0.80\right)$. The milk melamine concentration was linearly related with melamine intake $\left(\mathrm{R}^{2}=0.84\right)$. The present study demonstrated that when the daily intake of melamine exceeds $312.7 \mathrm{mg} /$ cow, the milk should not be used to produce infant formula powder.

Key words: melamine, dairy cow, milk, transfer efficiency

Received July 27, 2009.

Accepted January 6, 2010.

${ }^{1}$ Corresponding author: jqwangcaas@gmail.com

\section{INTRODUCTION}

Melamine (1,3,5-triazine-2,4,6-triamine) is mainly used for the production of melamine resins and plastics (Subrayan and Rasmussen, 1995; Weil and Choudhary, 1995). Melamine has also been marketed as a fertilizer because it contains $667 \mathrm{~g} / \mathrm{kg}$ of nitrogen (Shelton et al., 1997), which is also the reason for its consideration as a dietary NPN source for cattle. Unfortunately, available evidence shows that melamine is not an acceptable NPN source because of its stable and insoluble properties, which prevent melamine from being hydrolyzed and efficiently used in ruminal protein synthesis (Newton and Utley, 1978).

Melamine is believed to have low oral toxicity, but excessive intake by animals may cause crystalluria and renal damage. Therefore, melamine is not approved for use in animal feeds or human foods. Recently, melamine was found to have been added intentionally to animal feeds, even milk, to increase the apparent protein content. In March 2007, pet food ingredients contaminated with melamine and its analogs resulted in a major outbreak of renal disease and associated deaths in cats and dogs in the United States (Brown et al., 2007). In September 2008, high concentrations of melamine ranging from 0.090 to $2,563 \mathrm{mg} / \mathrm{kg}$ were detected in infant formula powder (Ministry of Health of the People's Republic of China, 2008a), which led to severe sickness in children and concerns in China (Ministry of Health of the People's Republic of China, 2008b). The US FDA (2007) reported that swine and fish feeds were also found to be tainted with melamine, with concentrations ranging from 30 to $120 \mathrm{mg} / \mathrm{kg}$ and 53 to $400 \mathrm{mg} / \mathrm{kg}$, respectively. With the possibility of melamine-tainted feed ingredients being sold to feed companies, it is reasonable to believe that cattle feed may also be contaminated with melamine.

After the media reports of melamine contamination of feed and milk powder, several countries established (interim) guidelines for maximum allowable levels of melamine in foods and feeds. The US FDA (2008a,b) concluded that melamine levels $<2.5 \mathrm{mg} / \mathrm{kg}$ in food and $<1 \mathrm{mg} / \mathrm{kg}$ in infant formula powder do not raise 
public health concerns. The Central People's Government of the People's Republic of China (2008) set the maximum level for infant formula powder and milk products at 1 and $2.5 \mathrm{mg} / \mathrm{kg}$, respectively. When melamine-contaminated milk is converted to milk powder, the melamine level would be concentrated approximately 8 -fold. Therefore, if raw milk contaminated with melamine at $0.125 \mathrm{mg} / \mathrm{kg}$ or $0.3125 \mathrm{mg} / \mathrm{kg}$ were used to produce infant formula powder and common milk powder, the melamine content would reach the respective maximum allowable levels of infant formula powder and common milk powder. Cruywagen et al. (2009) found that melamine could be transferred from feed to milk at a transfer efficiency of $2 \%$ when ingested at a level of $17.1 \mathrm{~g} / \mathrm{d}$. At that transfer efficiency, raw milk from dairy cows producing $20 \mathrm{~kg}$ of milk and ingesting 125 or $320 \mathrm{mg}$ of melamine daily should not be processed for infant formula powder or common milk powder, respectively.

Cruywagen et al. (2009) believed that dietary melamine concentration might have an effect on melamine transfer efficiency, but little information is known about the transfer efficiency of low doses of melamine from feed to milk. The aim of the study was to determine the transfer efficiency of low dietary levels of melamine from feed to milk and to study the relationship between melamine intake and milk melamine concentration in cows fed different levels of melamine.

\section{MATERIALS AND METHODS}

\section{Experimental Design and Treatments}

The current study was performed at the Beijing Chuangxin Dairy Farm (Beijing, China). Animals were cared for and handled following the guidelines established by the Institute of Animal Science, Chinese Academy of Agricultural Sciences, China. Health of the cows was monitored continuously before and during the experimental period.

Twenty-four multiparous Holstein cows, weighing 609 \pm 26 (SD) $\mathrm{kg}$ and $156 \pm 14$ (SD) DIM, were divided into 2 blocks based on milk yield (block 1: $<20 \mathrm{~kg} / \mathrm{cow}$ per day; block 2: $>20 \mathrm{~kg} /$ cow per day). The BW of each cow was calculated based on the measurement of heart girth and body length using the follow equation: BW $(\mathrm{kg})=$ heart girth ${ }^{2}(\mathrm{~m}) \times$ body length $(\mathrm{m}) \times 90$ (Wang, 2006). The milk yield of the cows was determined by averaging the milk yield on the $3 \mathrm{~d}$ immediately before the start of the feeding trial. The initial milk yields were $16.27 \pm 2.37(\mathrm{SD})$ and $24.49 \pm 2.83(\mathrm{SD}) \mathrm{kg} / \mathrm{d}$ for blocks 1 and 2, respectively. Cows in each block were then randomly assigned to 1 of 4 treatments, with each treatment having 6 cows. The initial milk yields were
$19.4 \pm 4.6(\mathrm{SD}) \mathrm{kg} / \mathrm{d}, 20.1 \pm 4.2(\mathrm{SD}) \mathrm{kg} / \mathrm{d}, 19.9 \pm 4.8$ (SD) $\mathrm{kg} / \mathrm{d}$, and $19.5 \pm 4.3$ (SD) kg/d for control, treatment 1 (Trt1), treatment 2 (Trt2), and treatment 3 (Trt3), respectively. Daily melamine intake of cows was 0 (control), $90 \mathrm{mg}$ (Trt1), $270 \mathrm{mg}$ (Trt302), and $450 \mathrm{mg}$ (Trt3), respectively. Melamine used in the treatments (99.8\% pure) was obtained from Yuhua Fine Chemistry Ltd. (Henan Province, China). The trial lasted for 19 d. During the first $13 \mathrm{~d}$ (feeding period), before each morning feeding, cows were allowed to consume all the added melamine mixed with about $35 \mathrm{~g}$ of concentrate (composed of $50 \%$ wheat bran and $50 \%$ corn powder). At the end of feeding period, the melamine was removed from the diet, and the cows were monitored for another $6 \mathrm{~d}$ (clearance period).

Cows were housed in a tie stall barn and had free access to water. Diets were formulated to meet nutrient requirements (China Standard NY/T 34, 2004) of cows weighing $600 \mathrm{~kg}$, averaging 150 DIM, and producing 25 $\mathrm{kg}$ of milk (35 g/ $\mathrm{kg}$ of fat). Ingredients and chemical composition of the basal diet are listed in Table 1. Feed was offered ad libitum plus $5 \%$, fed in equal amounts at 0500,1200 , and $1900 \mathrm{~h}$. Individual cow feed intake was measured and recorded daily. Cows were milked 3 times daily $(0400,1100$, and $1800 \mathrm{~h}$ ), and individual milk yield was recorded for each milking.

\section{Sampling and Analysis}

Before the trial started, melamine in the samples of feed ingredients and milk was analyzed to determine background concentration. During the entire experimental period, all feed ingredients came from the same batch except for bean curd residue. Each batch of bean curd residue was analyzed for melamine. No melamine was detected in any of the feed ingredients or milk samples collected before the feeding trial.

Individual milk samples were collected at each milking for 18 consecutive days (from d 2 to 19 of the experimental period). No milk samples were collected within the first $24 \mathrm{~h}$. Milk samples (approximately 150 $\mathrm{mL}$ ) from individual cows collected from the 3 daily milkings were mixed completely at a 4:3:3 ratio (a ratio reflecting the milk yield of the 3 milkings) and divided into small aliquots (50 mL each). One aliquot was stored at $-20^{\circ} \mathrm{C}$ immediately for analysis of melamine. Another aliquot, containing only milk collected at d $10,11,12$, and 13 of the feeding period, was stored at $4^{\circ} \mathrm{C}$ and analyzed for fat, protein, urea, lactose, casein, and total solids contents using infrared analysis (Foss MilkoScan, Foss Food Technology Corp., Eden Prairie, MN). All milk samples collected for milk composition determination were analyzed within $2 \mathrm{~d}$. 


\section{Determination of Melamine in Diets and Milk}

Melamine content in diets and milk was determined by GC-MS as described previously (China Standard NY/T 1372, 2007; China Standard GB/T 22388, 2008) with some modifications. External standards (SigmaAldrich, St Louis, MO) were prepared to provide a range between 0 and $0.5 \mu \mathrm{g} / \mathrm{mL}$. Briefly, the diet was finely ground to pass a 40 -mesh sieve. Then, $5 \mathrm{~g}$ of ground diet was dissolved in $50 \mathrm{~mL}$ of $1 \%$ trichloroacetic acid and $2 \mathrm{~mL}$ lead acetate $(22 \mathrm{~g} / \mathrm{L})$ was added to precipitate the proteins. Aliquots $(5 \mathrm{~mL})$ of raw milk were also processed similarly. After the extraction of the diet and the milk, the supernatant was centrifuged at $11,300 \times g$ for $5 \mathrm{~min}$, and $3 \mathrm{~mL}$ of supernatant was loaded onto a cation-exchange solid-phase extraction cartridge (Oasis MCX 3 cc, 60 mg; Waters, Dublin, Ireland), conditioned with $3 \mathrm{~mL}$ of methanol followed by $3 \mathrm{~mL}$ of distilled water. The cartridge was subsequently washed with $3 \mathrm{~mL}$ of distilled water followed by $3 \mathrm{~mL}$ of methanol. Thereafter, melamine was eluted by ammonia-methanol (5:95, vol/vol) and dried under a stream of nitrogen. The melamine was then dissolved in $600 \mu \mathrm{L}$ of pyridine and derivatized using $200 \mu \mathrm{L}$ of NO-Bis(trimethylsilyl)trifluoro acetamide (BSTFA) following incubation at $70^{\circ} \mathrm{C}$ for $30 \mathrm{~min}$. The detection limit for melamine was $0.02 \mathrm{mg} / \mathrm{kg}$ for milk samples and $0.05 \mathrm{mg} / \mathrm{kg}$ for feed samples.

\section{Statistical Analysis}

Milk yield, milk composition, milk melamine concentration, melamine excretion via milk, and transfer efficiency were analyzed using the MIXED procedures of SAS (version 9.0, SAS Institute Inc., Cary, NC). Because no melamine was detected in the control group, no statistical analyses were done on milk melamine of the control group. Fixed effects in the model included treatment, block, day, treatment $\times$ block interaction, and treatment $\times$ day interaction. Treatment $\times$ block $x$ day interaction was included in the residual term. The variance for cow nested within block $\times$ treatment, was used as random effect. The day of collection was a repeated measure (compound symmetry covariance structure). Differences among treatments were analyzed using Tukey's multiple range test, and $P$-values $\leq 0.05$ were considered statistically significant.

Transfer efficiency of ingested melamine to milk (Trt1, Trt2, and Trt3) was calculated separately for each cow, using the ratio between the mean daily amount of melamine ingested and that excreted in milk from d 3 to 13 of the feeding period. Transfer efficiency was regressed on milk yield over time of collection, and a linear equation was calculated. Regression analysis
Table 1. Ingredient and chemical composition of the basal diet (DM basis)

\begin{tabular}{|c|c|}
\hline Item & $\mathrm{g} / \mathrm{kg}$ of $\mathrm{DM}$ \\
\hline \multicolumn{2}{|l|}{ Ingredient } \\
\hline Corn silage & 279.0 \\
\hline Chinese wild rye & 91.0 \\
\hline Bean curd residue & 72.0 \\
\hline Concentrate supplement $^{1}$ & 247.0 \\
\hline Wheat bran & 125.0 \\
\hline Corn & 118.0 \\
\hline Corn embryo cake & 68.0 \\
\hline \multicolumn{2}{|l|}{ Chemical composition $^{2}$} \\
\hline $\mathrm{NE}_{\mathrm{L}}^{3}(\mathrm{MJ} / \mathrm{kg}$ of $\mathrm{DM})$ & 6.49 \\
\hline $\mathrm{CP}$ & 154.49 \\
\hline $\mathrm{NDF}$ & 407.42 \\
\hline $\mathrm{ADF}$ & 241.41 \\
\hline $\mathrm{Ca}$ & 10.19 \\
\hline $\mathrm{P}$ & 5.81 \\
\hline
\end{tabular}

${ }^{1}$ Concentrate supplement consisted of corn, soybean meal, dairy products, cottonseed meal, sunflower meal, corn distillers dried grains, calcium hydrogen phosphate, sodium chloride, vitamin $A$, vitamin $\mathrm{D}_{3}$, vitamin E, copper sulfate, ferrous sulfate, zinc sulfate, manganese sulfate, sodium selenite, etc. Contained per kilogram of concentrate supplement: $\mathrm{CP} \geq 200.0 \mathrm{~g}$, crude fiber $\leq 150.0 \mathrm{~g}$, ash $\leq 150.0 \mathrm{~g}$, Ca 6.0 to $20.0 \mathrm{~g}$, total $\mathrm{P}>4.0 \mathrm{~g}, \mathrm{NaCl} 3.0$ to $20.0 \mathrm{~g}$, Lys $>5.0 \mathrm{~g}, \mathrm{H}_{2} \mathrm{O}<130.0$ $\mathrm{g}$, vitamin $\mathrm{A} \geq 10.4 \mathrm{kIU}$, vitamin $\mathrm{D}_{3} \geq 1.4 \mathrm{kIU}, \mathrm{Cu} \geq 10 \mathrm{mg}, \mathrm{Fe} \geq 54$ $\mathrm{mg}, \mathrm{Mn} \geq 42 \mathrm{mg}, \mathrm{Zn} \geq 95 \mathrm{mg}$.

${ }^{2}$ Calculated from the analyzed value of the dietary ingredients.

${ }^{3}$ Calculated value (based on China Standard NY/t 34, 2004).

of average milk melamine concentration on melamine intake was also carried out for individual cows.

\section{RESULTS AND DISCUSSION}

\section{Milk Production and Composition}

Milk yield and composition of different treatments are summarized in Table 2. Neither milk yield nor milk composition was affected by supplementation with low levels of melamine in the diet. Previous studies demonstrated that although melamine was not a good NPN source for ruminants, it could be slowly degraded in the rumen (Newton and Utley, 1978). Clark (1966) demonstrated that after dosing 3 sheep with $10 \mathrm{~g}$ of melamine per day, blood urea and creatinine levels rose sharply. We presumed that milk urea content might also increase if cows were administered a high dose of melamine. However, the milk urea content was similar among the 4 treatments, which was probably because of the low doses of melamine supplemented. Similar results were obtained by Cruywagen et al. (2009) who found no effect on milk urea, fat, protein, lactose, or total solids content even at a higher melamine intake level $(17.1 \mathrm{~g} / \mathrm{d})$. The treatment $\times$ block interaction was significant for milk protein $(\mathrm{g} / \mathrm{kg})$ and total solids $(\mathrm{g} / \mathrm{kg})$, but future studies are needed to elucidate the reasons for this interaction. 


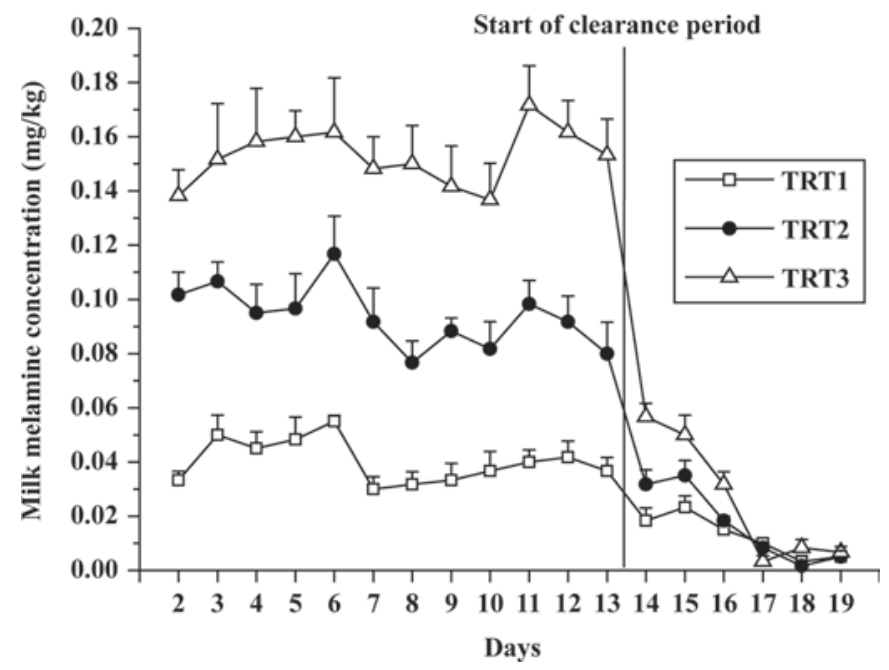

Figure 1. Melamine concentrations (mean \pm SE) in the milk of dairy cows fed 90 (treatment 1), 270 (treatment 2), or 450 (treatment 3) $\mathrm{mg}$ of melamine per day. For each treatment, each data point represents the mean of 6 cows. TRT $=$ treatment.

\section{Transfer Efficiency of Melamine from Feed to Milk}

During the experimental period, no melamine was detected in milk from the control group. Patterns of melamine concentrations in the milk of the Trt1, Trt2, and Trt3 groups are shown in Figure 1. Passage of melamine from feed to milk was detected in the milk of all the melamine-treated groups on the second day of the feeding period. Mean milk melamine concentrations increased consecutively during the initial $3 \mathrm{~d}$ of the feeding period in all melamine-treated groups, and then fluctuated to some extent over the remaining 10 $\mathrm{d}$ of the feeding period. Cruywagen et al. (2009) found that melamine appeared in the milk within $8 \mathrm{~h}$ after first melamine ingestion. In the current study, no milk sample was collected within $24 \mathrm{~h}$, so the exact time of first appearance of melamine was unknown. Baynes et al. (2008) reported that pig's blood would be cleared of about $99 \%$ of the melamine within $28 \mathrm{~h}$ after exposure. Mast et al. (1983) suggested that $90 \%$ of the administrated melamine was excreted in rat urine within $24 \mathrm{~h}$. Within $4 \mathrm{~d}$ of melamine administration being terminated (d 14), melamine could not be detected in milk from any of the treated groups (Figure 1). In fact, the clearance of melamine in milk was faster than that reported by Cruywagen et al. (2009), who found that the complete disappearance of milk melamine took more than $6 \mathrm{~d}$. This discrepancy might be attributable to differences in the amounts of melamine added to the diets and the sensitivity of the analytical method used in detecting melamine.

In the current study, mean milk melamine concentrations $(0.041,0.093$, and $0.154 \mathrm{mg} / \mathrm{L}$ for Trt1, Trt2, and Trt3, respectively) were significantly $(P<0.01)$ influenced by melamine feeding dose. However, the transfer efficiency $(0.95,0.70$, and $0.66 \%$ for Trt1, Trt2, and Trt3, respectively) was not associated with melamine intake (Table 3). Another finding of this study was that milk yield (16.31 kg for block 1 and $23.04 \mathrm{~kg}$ for block 2) had a significant effect on transfer efficiency from feed to milk $(0.557 \%$ for block 1 and $0.948 \%$ for block 2; Table 3). It appears that high-producing cows can excrete more melamine than low-producing cows. A similar result was found in the transfer of aflatoxin from feed to milk in dairy cows by Masoero et al. (2007), who concluded that milk yield was the major factor affecting the total excretion of aflatoxin M1. No

Table 2. Least squares means of daily milk yield and composition of the experimental groups that received different doses of melamine (d 10 to 13$)$

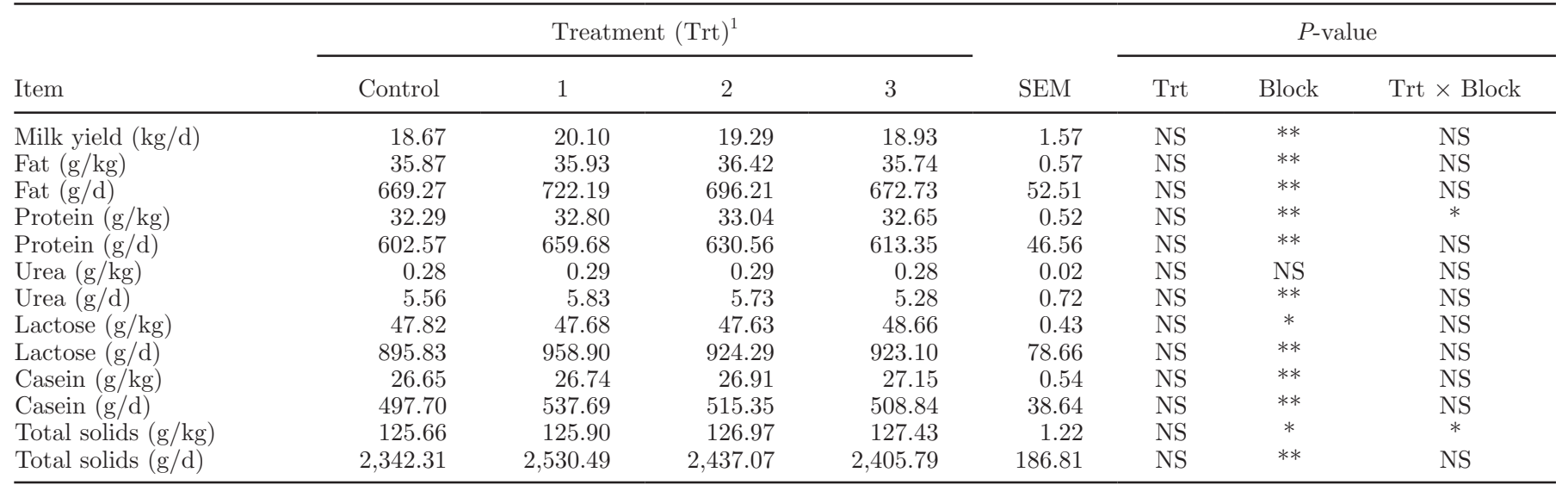

${ }^{1}$ Treatment: Cows were administrated with melamine at $0,90,270$, and $450 \mathrm{mg} / \mathrm{d}$ per cow for control, and treatments 1,2 , and 3 , respectively.

${ }^{* *} P<0.01 ;{ }^{*} P<0.05 ; \mathrm{NS}=P>0.05$. 


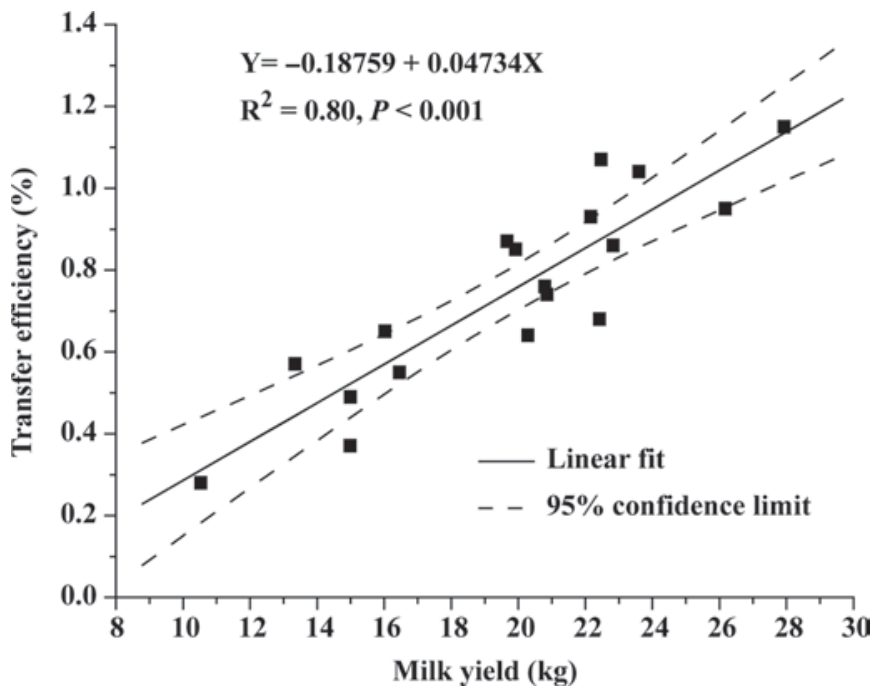

Figure 2. Relationship of milk yield (x) with transfer efficiency (y) of melamine from feed to milk.

significant treatment $\times$ block interaction was found for milk melamine concentration, melamine excretion via milk, or transfer efficiency.

Under the experimental conditions used in this study, the relationship between transfer efficiency (\%) and milk yield $(\mathrm{kg})$ can be described by the following equation (Figure 2):

$$
\begin{gathered}
\text { Transfer efficiency }(\%)=-0.18759+0.04734 \\
\times \text { milk yield }(\mathrm{kg}), \\
\mathrm{R}^{2}=0.80 ; P<0.001 .
\end{gathered}
$$

Cruywagen et al. (2009) demonstrated that melamine excretion via milk accounted for about $2 \%$ of the ingested melamine for cows producing $24.9 \mathrm{~kg}$ of milk per day. At this milk yield, the $95 \%$ confidence interval for transfer efficiency would be $0.991 \pm 0.085 \%$, which is about one-half of the value observed by Cruywagen et al. (2009). Cruywagen et al. (2009) speculated that dietary melamine concentrations might affect transfer efficiency. Within the narrow melamine dosage range used in our current study, transfer efficiency was not affected by the melamine feeding doses. We speculated that when a high level of melamine is fed, the limited ruminal degradation of melamine would result in relatively large amounts of melamine bypassing the rumen. As a result, more melamine could be absorbed into the blood in the lower digestive tract, which would lead to a higher level of melamine in the milk. More research is needed to confirm this hypothesis. Some other factors, such as forage to concentrate ratios and amount of water intake, may also affect the transfer efficiency of melamine from feed to milk.

The relationship between milk melamine concentration $(\mathrm{y})$ and melamine intake $(\mathrm{x})$ was calculated using the concentrations from d 3 to 13 of the feeding period, and was expressed by the equation

$$
\mathrm{y}(\mathrm{mg} / \mathrm{kg})=0.01064+0.00031574 \mathrm{x}(\mathrm{mg} / \mathrm{d} \text { per cow }) \text {, }
$$

$\mathrm{R}^{2}=0.84 ; F$-test: $P<0.001 ;$ lack of fit test: $P=0.69$.

Therefore, milk melamine concentration increases linearly as melamine intake increases. It can be calculated from the above regression that with a daily melamine intake of $<29.6 \mathrm{mg} / \mathrm{cow}$, milk melamine concentration would be below the detection limit $(<0.02 \mathrm{mg} / \mathrm{kg})$. The regression also implies that when cows consume diets that do not contain any detectable levels of melamine, the milk can also be expected to contain no detectable melamine.

When milk melamine concentration was regarded as independent variable $(\mathrm{x})$ and melamine intake as dependent variable (y), the relationship between milk melamine concentration and melamine intake could be

\begin{tabular}{|c|c|c|c|c|c|c|c|}
\hline \multirow[b]{2}{*}{ Item } & \multicolumn{3}{|c|}{ Treatment $(\text { Trt })^{1}$} & \multirow[b]{2}{*}{ SEM } & \multicolumn{3}{|c|}{$P$-value ${ }^{2}$} \\
\hline & 1 & 2 & 3 & & Trt & Block & Trt $\times$ Block \\
\hline Milk melamine $(\mathrm{mg} / \mathrm{kg})$ & $0.041^{\mathrm{c}}$ & $0.093^{\mathrm{b}}$ & $0.154^{\mathrm{a}}$ & 0.008 & $* *$ & NS & NS \\
\hline Transfer efficiency (\%) & 0.948 & 0.695 & 0.655 & 0.074 & NS & ** & NS \\
\hline
\end{tabular}
expressed by the equation

Table 3. Least squares means of concentration, excretion, and transfer efficiency of dietary melamine to milk of the treated groups that received different doses of melamine (d 3 to 13 )

${ }^{\mathrm{a}-\mathrm{c}}$ Means within a row with different superscripts differ $(P<0.05)$.

${ }^{1}$ Treatment: Cows were fed diets with calculated daily melamine intakes of 90,270 , and $450 \mathrm{mg} / \mathrm{cow}$ for treatments 1,2 , and 3 , respectively. ${ }^{2}$ Least squares means of milk melamine concentration, melamine excretion via milk, and transfer efficiency were 0.086 vs. $0.106,1.39^{\mathrm{b}}$ vs. $2.39^{\mathrm{a}}$, and $0.557^{\mathrm{b}}$ vs. $0.948^{\mathrm{a}}$ for block 1 vs. block 2 .

${ }^{*} * P<0.01 ; \mathrm{NS}=P>0.05$. 


$$
\begin{gathered}
\mathrm{y}(\mathrm{mg} / \mathrm{d} \text { per cow })=13.42005 \\
+2,675.80528 \mathrm{x}(\mathrm{mg} / \mathrm{kg}) \\
\mathrm{R}^{2}=0.84 ; \text { F-test: } P<0.001
\end{gathered}
$$

If milk melamine concentration were 0.125 or 0.3125 $\mathrm{mg} / \mathrm{kg}$, the $95 \%$ confidence interval for the mean melamine intake would be $347.9 \pm 35.2 \mathrm{mg}$ and $849.6 \pm$ $134.5 \mathrm{mg}$, respectively. The US FDA (2008a,b) and The Central People's Government of the People's Republic of China (2008) both set the maximum melamine levels for infant formula powder and common milk powder at 1 and $2.5 \mathrm{mg} / \mathrm{kg}$. Milk melamine concentration of 0.125 or $0.3125 \mathrm{mg} / \mathrm{kg}$ are much lower than the interim limit value of melamine in liquid milk $(2.5 \mathrm{mg} / \mathrm{kg})$, but if such milk were converted to milk powder, the melamine concentration would reach the maximum allowable level of $1 \mathrm{mg} / \mathrm{kg}$ in infant formula powder and $2.5 \mathrm{mg} / \mathrm{kg}$ in common milk powder. In melamine-treated groups, milk melamine concentration had a certain root mean square error with a coefficient of variation up to $22.7 \%$. Therefore, we used the lower limit of the 95\% confidence interval for prediction of melamine intake that would affect the milk melamine content to an extent problematic for human safety. So, if the mean daily intake of melamine by a dairy cow exceeds $312.7 \mathrm{mg}$, the milk should not be used to produce infant formula. If it exceeds $715.1 \mathrm{mg}$, the milk should not be used to produce common milk powder. An intake value of $715.1 \mathrm{mg} / \mathrm{d}$ per cow was outside the range of this study. More research is needed to confirm this finding. This result was different from what we calculated using the transfer efficiency reported by Cruywagen et al. (2009). Thus, the regression equation is only applicable when the melamine doses fall within the range used in this study, and any inference beyond the melamine doses used in this study needs to be confirmed in future studies.

\section{CONCLUSIONS}

In this study, it appeared that milk melamine concentration was significantly affected by melamine feeding doses but was not influenced by milk yield. On the contrary, the transfer efficiency of melamine from feed to milk was not affected by melamine dose but was affected by and linearly related to milk yield. The milk melamine concentration was linearly related to melamine intake within the narrow range used in this study. It can be calculated from the regression that when the daily intake of melamine exceeds $312.7 \mathrm{mg} /$ cow, the lower limit of the $95 \%$ confidence interval, the milk should not be used to produce infant formula powder.

\section{ACKNOWLEDGMENTS}

This study was financially supported by an earmark fund for Melamine Limit in Feed from the Ministry of Agriculture and by an earmark fund for Modern AgroIndustry Technology Research System of the P. R. China. We thank the staff of the State Key Laboratory of Animal Nutrition and the Milk and Dairy Inspection and Supervision Center of Ministry of Agriculture for technical assistance. We also acknowledge the kind contributions of Z. T. Yu (Ohio State University, Columbus), A. F. Kertz (ANDHIL LLC, St. Louis, MO), and the personnel of the Beijing Chuangxin dairy farm to this work.

\section{REFERENCES}

Baynes, R. E., G. Smith, S. E. Mason, E. Barrett, B. M. Barlow, and J. E. Riviere. 2008. Pharmacokinetics of melamine in pigs following intravenous administration. Food Chem. Toxicol. 46:1196-1200.

Brown, C. A., K. S. Jeong, R. H. Poppenga, B. Puschner, D. M. Miller, A. E. Ellis, K. I. Kang, S. Sum, A. M. Cistola, and S. A. Brown. 2007. Outbreaks of renal failure associated with melamine and cyanuric acid in dogs and cats in 2004 and 2007. J. Vet. Diagn. Invest. 19:525-531.

China Standard GB/T 22388. 2008. Determination of melamine in raw milk and dairy products. Issued by General Administration of Quality Supervision, Inspection and Quarantine of the People's Republic of China (AQSIQ) and Standardization Administration of the People's Republic of China (SAC).

China Standard NY/T 1372. 2007. Determination of melamine in feeds. Issued by Ministry of Agriculture of the People's Republic of China.

China Standard NY/T 34. 2004. Feeding Standard of Dairy Cattle. China NongYe HangYe Biaozhun/Tuijian-34. China Agricultural Publisher, Beijing, China.

Clark, R. 1966. Melamine crystalluria in sheep. J. S. Afr. Vet. Med. Assoc. 37:349-351.

Cruywagen, C. W., M. A. Stander, M. Adonis, and T. Calitz. 2009. Hot topic: Pathway confirmed for the transmission of melamine from feed to cow's milk. J. Dairy Sci. 92:2046-2050.

Masoero, F., A. Gallo, M. Moschini, G. Piva, and D. Diaz. 2007. Carryover of aflatoxin from feed to milk in dairy cows with low or high somatic cell counts. Animal 1:1344-1350.

Mast, R. W., A. R. Jeffcoat, B. M. Sadler, R. C. Kraska, and M. A. Friedman. 1983. Metabolism, disposition and excretion of $\left[{ }^{14} \mathrm{C}\right]$ melamine in male Fischer 344 rats. Food Chem. Toxicol. 21:807810.

Ministry of Health of the People's Republic of China. 2008a. Press conference on testing melamine in baby milk formula. http:// www/moh.gov.cn/publicfiles/buusiness/htmlfiles/mohbgt/s3582/ 200809/37917.htm Accessed Jan. 7, 2009.

Ministry of Health of the People's Republic of China. 2008b. Report on the treatment of children suffering from melamine-tainted milk formula. http://www.moh.gov.cn/publicfiles/business/htmlfiles/ mohbgt/s3582/200809/37957.htm Accessed Jan. 7, 2009.

Newton, G. L., and P. R. Utley. 1978. Melamine as a dietary nitrogen source for ruminants. J. Anim. Sci. 47:1338-1344.

Shelton, D. R., J. S. Karns, G. W. Mccarty, and D. R. Durham. 1997. Metabolism of melamine by Klebsiella terragena. Appl. Environ. Microbiol. 1997:2832-2835. 
Subrayan, R. P., and P. G. Rasmussen. 1995. An overview of materials composed of carbon and nitrogen. Trends Polym. Sci. (Regul. Ed.) $3: 165-172$.

The Central People's Government of the People's Republic of China. 2008. Proclamation 25, 2008. Ministry of Health, Ministry of Industry and Information Technology, Ministry of Agriculture, State Administration For Industry \& Commerce, General Administration of Quality Supervision, Inspection and Quarantine of the People's Republic of China. http://www.moh.gov.cn/sofpro/ cms/previewjspfile/wsb/cms_0000000000000000207_tpl.jsp?reque stCode $=38033 \&$ CategoryID $=7987$. Accessed Dec. 7, 2008 .

US FDA. 2007. Interim Melamine and Analogues Safety/Risk Assessment. http://www.foodsafety.gov/ dms/melamra.html Accessed Dec. 25, 2008.
US FDA. 2008a. Interim Safety and Risk Assessment of Melamine and its Analogues in Food for Humans. http://www.fda.gov/OHRMS/ DOCKETS/98fr/FDA-2008-N-0574-bkg.pdf Accessed May 5, 2009.

US FDA. 2008b. Update: Interim Safety and Risk Assessment of Melamine and its Analogues in Food for Humans. http://www. fda.gov/Food/FoodSafety/FoodContaminantsAdulteration/ ChemicalContaminants/Melamine/ucm164520.htm Accessed Dec. $28,2008$.

Wang, J. Q. 2006. Modern Dairy Production Science. China Agricultural Press, Beijing, China. (In Chinese)

Weil, E. D., and V. Choudhary. 1995. Flame-retarding plastics and elastomers with melamine. J. Fire Sci. 13:104-126. 